\title{
Short-term movements and diving behaviour of satellite-tracked blue sharks Prionace glauca in the northeastern Atlantic Ocean
}

\author{
Nuno Queiroz ${ }^{1,2,3}$, Nicolas E. Humphries ${ }^{1}$, Leslie R. Noble $^{3}$, \\ António M. Santos ${ }^{2}$, David W. Sims ${ }^{1,4, *}$ \\ ${ }^{1}$ Marine Biological Association of the United Kingdom, The Laboratory, Citadel Hill, Plymouth PL1 2PB, UK \\ ${ }^{2}$ CIBIO - U.P., Centro de Investigação em Biodiversidade e Recursos Genéticos, Campus Agrário de Vairão, \\ Rua Padre Armando Quintas, 4485-668 Vairão, Portugal \\ ${ }^{3}$ School of Biological Sciences, University of Aberdeen, Tillydrone Avenue, Aberdeen AB24 2TZ, UK \\ ${ }^{4}$ Marine Biology and Ecology Research Centre, School of Marine Sciences and Engineering, University of Plymouth, \\ Drake Circus, Plymouth PL4 8AA, UK
}

\begin{abstract}
Shifts in the movement, activity or behaviour of individual animals in relation to changing environmental landscapes play an important role in determining re-distribution patterns of populations. Such spatial dynamics are poorly understood for pelagic sharks despite the decline of many species due to overfishing. Satellite-linked archival transmitters were used to record the movements of blue sharks Prionace glauca for the first time in the northeast Atlantic. A total of 256 tracking days were recorded, with sharks covering an estimated minimum distance of $11432 \mathrm{~km}$. Generally, blue sharks displayed wide-ranging southward movements away from the tagging areas (English Channel, southern Portugal and the Azores Islands), with juvenile sharks displaying less site fidelity than previously suggested from other methods. Vertical movements ranged from the surface to a maximum depth of $696 \mathrm{~m}$, and water temperatures varied from 10.6 to $24.6^{\circ} \mathrm{C}$. Shifts in both thermal and depth-use patterns were detected, with tracked sharks displaying behavioural variability correlated with the environment, both within and between individuals. Patterns of behaviour in coastal areas were generally linked to the thermal structure of the water column; sharks displayed some preference for surface layers in thermally stratified waters, but displayed less regular behaviour in wellmixed or weakly stratified waters. In offshore locations, sharks usually adopted either a surfaceoriented or a depth-oriented diving pattern, often switching between both in response to probable changes in prey distribution or prey type when in deeper water. Fishing-induced mortality of tracked sharks was approximately $10 \%$ during the period of 13 to $70 \mathrm{~d}$ post-tagging. Our results indicate a variety of short and longer range movements of juvenile and sub-adult blue sharks with respect to time and environment in the northeast Atlantic, which suggests complex spatial dynamics and population structuring in this exploited species.
\end{abstract}

KEY WORDS: Behaviour $\cdot$ Habitat use $\cdot$ Variability $\cdot$ Telemetry $\cdot$ Diving patterns

Resale or republication not permitted without written consent of the publisher

\section{INTRODUCTION}

The advent of electronic tagging has enabled behavioural studies on movements/migrations, diving behaviour and habitat use in a variety of free-ranging marine species (e.g. Sims et al. 2003b, Wall et al. 2007).
Several of these tracking studies have identified variability in the behaviour of marine fish, turtles, birds and mammals, indicating that this may be a common feature (Folkow et al. 2004, Green et al. 2005, Hays et al. 2006, Teo et al. 2007). For example, temporal shifts in behaviour have frequently been recognised at dif- 
ferent seasonal and/or diel scales. Differences in diving or dispersal patterns at different times of the year have been observed in many pinniped species (Folkow \& Blix 1999, Folkow et al. 2004), penguins (Charrassin \& Bost 2001, Green et al. 2005) and sharks (Carey \& Scharold 1990, Hulbert et al. 2005); such differential patterns have been attributed to sexual activity, habitat characteristics and prey type. Diel variations in behaviour, especially in vertical movements, have also been observed in a large number of marine predators. While some species show a pronounced alternation between the occupation of warm surface waters at night and deep cold waters during the day (bigeye tuna Thunnus obesus, Dagorn et al. 2000; bigeye thresher shark Alopias superciliosus, Nakano et al. 2003; swordfish Xiphias gladius, Takahashi et al. 2003), other species, such as blue Prionace glauca and shortfin mako Isurus oxyrinchus sharks, bluefin tuna Thunnus thynnus and black marlin Makaira nigricans, usually display regular vertical movements, performing the deepest dives during daylight and spending nighttime at shallower depths (Carey \& Scharold 1990, Holts \& Bedford 1993, Lutcavage et al. 2000, Gunn et al. 2003). The differences between day and night behaviour likely relate to the movements and availability of prey (West \& Stevens 2001, Hays et al. 2004, Sims et al. 2005).

Intra-individual differences have been less well documented, although it is unclear whether this is because such patterns rarely occur or whether it is only recently that animals have been tracked with sufficient spatial and temporal resolution to identify such transitions (Shepard et al. 2006). Recent examples indicate significant shifts in movement patterns, diving behaviour and thermal biology in Atlantic bluefin tuna at different stages of the breeding cycle (Teo et al. 2007), whilst abrupt changes were observed in the swimming behaviour of individual white sharks Carcharodon carcharias (Bruce et al. 2006) and in the depth use of basking sharks Cetorhinus maximus (Shepard et al. 2006). Knowing how individual behaviour varies across a range of spatio-temporal scales is an essential step towards understanding habitat selection processes in large marine animals (Sims et al. 2006a). Habitat use is a necessary prerequisite for predicting the movements and distribution of marine species in relation to environmental change, which is critical for the development of management and conservation plans (McMahon \& Hays 2006).

Acoustic tracking of blue shark in the northwest Atlantic revealed seasonal differences in diving behaviour (Carey \& Scharold 1990). Regular deep diving was observed in sharks tracked in the months of August to March, but not in sharks tracked during May to July. Since seasonal differences in diving behaviour have been described for blue sharks, it is therefore feasible that intra-individual behavioural shifts also occur within this species in response to shorter-scale temporal changes. However, although some tracking studies have been undertaken in the northwest Atlantic to elucidate short-term movements (over a period of days), there have been no similar studies in the northeast Atlantic, even though this region appears important to key life history components of the population (Stevens 1990).

In the Atlantic Ocean, the blue shark ranges from Newfoundland to Argentina in the west, over the entire mid-Atlantic, and from Norway to South Africa in the east (including the Mediterranean). Markrecapture studies in the Atlantic over the last $30 \mathrm{yr}$ suggest that different segments of the population (i.e. juveniles and adults, males and females) exhibit disparate movement patterns (Stevens 1976, 1990, Casey 1985). In the western Atlantic, the population mainly comprises juveniles of both sexes and adult males. It is thought that sub-adult and adult females mate with adult males and move offshore in the spring; they probably do not return, since mature females are extremely rare in inshore areas off North America (Casey 1985). Conventional tagging data suggests that females move into eastern Atlantic waters (Stevens 1990, Mejuto et al. 2003). As adults of both sexes are found in the eastern Atlantic during spring and summer, it is thought that mating occurs at this time (Stevens 1990). Adult females, many of which are pregnant, are found around the Canary Islands and North Africa in winter, while mature males are found further north off Portugal, along with juveniles and sub-adult females. Catch rates of young-of-the-year blue sharks indicate that parturition occurs in nurseries off the Iberian Peninsula, particularly off Portugal but also in the Bay of Biscay (Stevens 1990, Litvinov 2006). As juveniles are not known from the western Atlantic, it seems likely that the eastern Atlantic is an important breeding area for the north Atlantic blue shark population (Stevens 1990, Kohler et al. 2002). Trans-Atlantic movements of up to $7176 \mathrm{~km}$ have been shown by some individuals, indicating that they may travel round the entire north Atlantic gyre (Casey 1985, Stevens 1990). In addition, seasonal north-south movements, such as the summer migration into the western English Channel and Irish waters (Stevens 1976, Henderson et al. 2001) and the existence of trans-equatorial movements linking the northern and southern hemispheres of the Atlantic Ocean, have also been observed (Stevens 1990).

These differences in seasonal presence of blue sharks of different size and sex in the northeast Atlantic compared to the northwest, indicate complex 
population structuring and behaviour over a wide range of spatio-temporal scales on the basis of coarse mark-recapture and fisheries catch data. However, basic data are lacking on the detailed movements undertaken by individuals within these different northeast Atlantic population components. Therefore, the purpose of the present study was to describe the movements, diving behaviour and habitats (vertical, thermal) occupied by blue sharks in the northeastern Atlantic using pop-off satellite-linked archival transmitters (PSATs).

\section{MATERIALS AND METHODS}

Shark tagging. Between July 2006 and October 2007, a total of 11 blue sharks were tagged with PSAT tags in 3 areas: the English Channel off southwest England, off south Portugal, and south of the Azores archipelago (see Fig. 1). Shark 1 was tagged with a Mark 4 pop-up archival transmitting (PAT) tag (PAT4, Wildlife Computers) with an Argos-certified satellite transmitter, which records depth (maximum: $1000 \mathrm{~m}$; accuracy: $0.5 \mathrm{~m}$ ), water temperature (range: -40 to $60^{\circ} \mathrm{C}_{\text {; }}$ accuracy: $0.05^{\circ} \mathrm{C}$ ) and light level (at $550 \mathrm{~nm}$ wavelength). The remaining 10 sharks (Sharks 2 to 11) were tagged with Mk10 PAT tags (Wildlife Computers). Parameters were sampled at varying intervals (from 1 to $10 \mathrm{~s}$ ) and stored as summary data over set intervals of 4 or $6 \mathrm{~h}$, providing time-at-depth and time-at-temperature histograms as well as profiles of water temperature at depth. Tags were programmed to detach $30,60,90$ or $120 \mathrm{~d}$ after deployment and were attached to sharks via a $20 \mathrm{~cm}$ long monofilament (250 lb test) tether connected to a $5 \mathrm{~cm}$ long stainless steel T-bar arrowhead; the arrowhead was inserted into the dorsal musculature at a $45^{\circ}$ angle to a maximum depth of $10 \mathrm{~cm}$. In coastal locations off England and Portugal, blue sharks were caught using rod and line, brought onboard and in less than $5 \mathrm{~min}$ were measured, sexed and tagged prior to release. Off the Azores, sharks were captured on baited longlines deployed from a commercial fishing vessel. Sharks were brought alongside the vessel in the beginning of the gear-hauling phase and their general state evaluated. Sharks that were active, not deeply hooked and that had no major body damage were brought onboard, measured, sexed and tagged.

Track reconstruction. Blue shark movements were estimated using either satellite relayed data from each tag or from archival data after the tags were physically retrieved. Daily maximal rate of change in light intensity data were used to estimate local time of midnight or midday for longitude calculations using software provided by the tag manufacturer
(WC-GPE global position estimator program suite, Wildlife Computers). Anomalous longitude estimates resulting from dive-induced shifts in the estimated timings of dawn and dusk were discarded. Geolocations $>3^{\circ}$ of longitude from the previous longitude estimate were also removed (Sims et al. 2006b). Latitude along the longitude was then estimated by matching minimum and maximum tag-recorded water temperatures from the shallowest bin recorded in each period to sea surface temperature (SST) values on night-time, $8 \mathrm{~d}$ composite, moderate resolution imaging spectroradiometer (MODIS) remote-sensing images. The most parsimonious location was derived by matching individual pixel SSTs within a variablesized circular area (radius $=100$ to $500 \mathrm{~km}$ ) around the previous tag position. If no matches were made within the smaller area, the radius was increased until matches occurred. Variable-sized areas were used because geolocations at constant intervals were not always determined due to gaps in the data. A geographic mean position was calculated from all possible pixel locations within this area to derive each shark position. Maximum dive depth on the day each position was estimated was compared with seabed depths from a digital bathymetry map within each area to filter anomalous positions where the dive depth was greater than seabed depth. Using the ArcMap geographical information system (ESRI), intermediate waypoints were applied to track steps where trajectories between located positions crossed land. The final estimated positions were then analysed point-to-point with a $1 \mathrm{~m} \mathrm{~s}^{-1}$ swim speed filter, which is the maximum over-the-ground swimming speed measured for blue sharks (Carey \& Scharold 1990) and is consistent with swimming speeds of other pelagic sharks. Adjacent positions separated by a distance greater than the distance imposed by the speed filter were shifted to a location along the track where the forced speed limit provided an acceptable distance. Previous studies using this method estimated the mean error distance of light/SST geolocation compared to tagging or pop-up locations to be $75.5 \mathrm{~km} \pm 54.5 \mathrm{SD}$ (range: 36.9 to $183.9 \mathrm{~km}$; Sims et al. 2006b) and $78.0 \mathrm{~km} \pm 21.4 \mathrm{SD}$ (range: 54.7 to $100.0 \mathrm{~km}$; Pade et al. 2009).

Vertical movement analysis. A modified version of the split moving window (SMW) method (Cornelius \& Reynolds 1991) was employed to detect objectively significant shifts in time-at-depth (TAD) and time-at-temperature (TAT) data. Briefly, a variable-sized split window ranging from 4 or $6 \mathrm{~h}$ to a maximum of $5 \mathrm{~d}$ was used to compute dissimilarities between the 2 halves of the window along the time steps of the vertical track. A multivariate measure of dissimilarity (Euclidean) was computed between every possible pair of samples from 
different halves and the values of all comparisons were then averaged. The value obtained was assigned to the centre of the window, which then moved one step forward. Statistical significance of dissimilarities for each window's midpoint was computed using a randomisation technique. The process was then repeated until the window reached the end of the data series. The result from each window size was then plotted by piling them vertically, resulting in an inverted triangle with the lower vertex pointing to the boundary location whenever a significant shift was detected (see Figs. S1 \& $\mathrm{S} 2$ in the supplement; www.int-res.com/articles/ suppl/m406p265_app.pdf). This modified method has the advantage of not requiring evenly distributed data, making it suitable for satellite-transmitted summary data (given that it often has gaps due to the limited bandwidth of the Argos satellite relay system).

\section{RESULTS}

Six females, ranging in size from 130 to $199 \mathrm{~cm}$ fork length (FL), were tagged off southwest England (Table 1). Based on length at maturity measurements, these included juveniles, sub-adults and 1 adult female (Pratt 1979). A further 3 juvenile females were tagged off south Portugal. Two mature males (presence of elongated and rigid calcified claspers was confirmed) were tagged in the Azores. Overall, 2 tags failed to report data and 7 detached prematurely after 13 to $42 \mathrm{~d}$. Of these, 2 tags were physically recovered after being washed ashore. Shark 5 (S5) was caught by a Spanish longliner after $70 \mathrm{~d}$ at liberty. Data after the time of premature release of tags was disregarded. Only the tag attached to Shark 1 (S1) reached the popup date. Altogether, blue sharks were tracked for a combined total of $256 \mathrm{~d}$, covering an estimated minimum distance of $11432 \mathrm{~km}$ (Table 1).

\section{Horizontal movements}

In general, blue sharks showed fast, wide-scale southward movements away from the tagging area (Figs. 1A \& 2). The mature female shark (S1) was the only shark that remained within a localised shallow region, initially in the English Channel, then later it moved southwest onto the continental shelf edge in late July where the tag popped up (Fig. 1A,B). Sharks 2 to 4 (S2 to S4) initially moved into the Bay of Biscay shelf edge area prior to moving offshore into deep oceanic water (Fig. 1A,C,D,E). S3 was later geolocated near the Spanish north coast, approximately $17 \mathrm{~d}$ after tagging. Unlike these individuals, S5 initially moved south, arriving at the Bay of Biscay in late August (Fig. 1A,F). The shark continued to move southeast along the continental shelf edge for $18 \mathrm{~d}$ before moving into deep water. In late September, estimated geolocations placed S5 on the northern Spanish coast. By early November, the shark had moved north (Fig. 2) and was captured near the shelf edge. After an initial northward movement into the Portuguese west coast shelf area, Shark 6 (S6) was geolocated southwest of the tagging location over deep water (Fig. 1A,G). Sharks 7 and 8 (S7, S8) initially moved southeast off the African coast (Fig. $1 \mathrm{~A}, \mathrm{I}, \mathrm{H})$, while $\mathrm{S} 8$ continued to move southwest along the African coast and was geolocated near the Canary Islands by mid-November. The only male for which data was received, Shark 9 (S9), displayed a clear southward movement of approximately $1500 \mathrm{~km}$ after being tagged off the Azores Islands (Fig. 1A,J).

\section{Vertical movements and behaviour}

Blue sharks occupied a broad vertical habitat, from the surface to a maximum depth of $696 \mathrm{~m}$; water temperatures spanned a $14^{\circ} \mathrm{C}$ range from 10.6 to $24.6^{\circ} \mathrm{C}$.

Table 1. Prionace glauca. Pop-up satellite tagged blue shark summary data. F: female; M: male; -: tags did not report

\begin{tabular}{|c|c|c|c|c|c|c|c|c|c|c|c|}
\hline \multirow[t]{2}{*}{ ID } & \multirow{2}{*}{$\begin{array}{c}\text { Fork } \\
\text { length } \\
(\mathrm{cm})\end{array}$} & \multirow[t]{2}{*}{ Sex } & \multirow[t]{2}{*}{$\begin{array}{c}\text { Location } \\
\text { tagged }\end{array}$} & \multirow[t]{2}{*}{$\begin{array}{l}\text { Date } \\
\text { tagged }\end{array}$} & \multirow[t]{2}{*}{$\begin{array}{c}\text { Release } \\
\text { days }\end{array}$} & \multicolumn{2}{|c|}{$\begin{array}{l}\text { Pop-up } \\
\text { location }\end{array}$} & \multirow[t]{2}{*}{$\begin{array}{l}\text { Pop-up } \\
\text { date }\end{array}$} & \multirow[t]{2}{*}{$\begin{array}{l}\text { Days-at } \\
\text { liberty }\end{array}$} & \multirow{2}{*}{$\begin{array}{c}\text { Minimum } \\
\text { distance } \\
(\mathrm{km})\end{array}$} & \multirow{2}{*}{$\begin{array}{c}\text { Minimum } \\
\text { distance } \\
\mathrm{d}^{-1}(\mathrm{~km})\end{array}$} \\
\hline & & & & & & ${ }^{\circ} \mathrm{N}$ & ${ }^{\circ} \mathrm{W}$ & & & & \\
\hline Shark 1 & 199 & $\mathrm{~F}$ & England & $06 \mathrm{Jul} 06$ & 30 & 48.24 & 05.99 & 05 Aug 06 & 30 & 1058 & 35.27 \\
\hline Shark 2 & 153 & $\mathrm{~F}$ & England & $21 \mathrm{Jul} 06$ & 60 & 45.86 & 09.52 & 10 Aug 06 & 20 & 1403 & 70.15 \\
\hline Shark 3 & 130 & $\mathrm{~F}$ & England & 08 Aug 06 & 60 & 44.00 & 07.91 & 29 Aug 06 & 21 & 848 & 40.38 \\
\hline Shark 4 & 130 & $\mathrm{~F}$ & England & 01 Aug 07 & 60 & 46.38 & 10.63 & 14 Aug 07 & 13 & 907 & 69.77 \\
\hline Shark 5 & 150 & $\mathrm{~F}$ & England & 21 Aug 07 & 90 & 46.83 & 05.80 & 02 Nov 07 & 70 & 2789 & 39.84 \\
\hline Shark 6 & 95 & $\mathrm{~F}$ & Portugal & 10 Oct 06 & 60 & 34.23 & 12.40 & 30 Oct 06 & 20 & 614 & 30.70 \\
\hline Shark 7 & 110 & $\mathrm{~F}$ & Portugal & 12 Oct 06 & 120 & 34.64 & 07.42 & 28 Oct 06 & 16 & 268 & 16.75 \\
\hline Shark 8 & 115 & $\mathrm{~F}$ & Portugal & 04 Oct 07 & 60 & 28.18 & 14.70 & 15 Nov 07 & 42 & 2029 & 48.31 \\
\hline Shark 9 & 199 & M & Azores & 17 Jun 07 & 60 & 30.62 & 24.96 & $11 \mathrm{Jul} 07$ & 24 & 1516 & 63.17 \\
\hline Shark 10 & 162 & $\mathrm{~F}$ & England & 08 Aug 06 & 120 & - & - & - & - & - & - \\
\hline Shark 11 & 192 & M & Azores & 17 Jun 07 & 90 & - & - & - & - & - & - \\
\hline
\end{tabular}



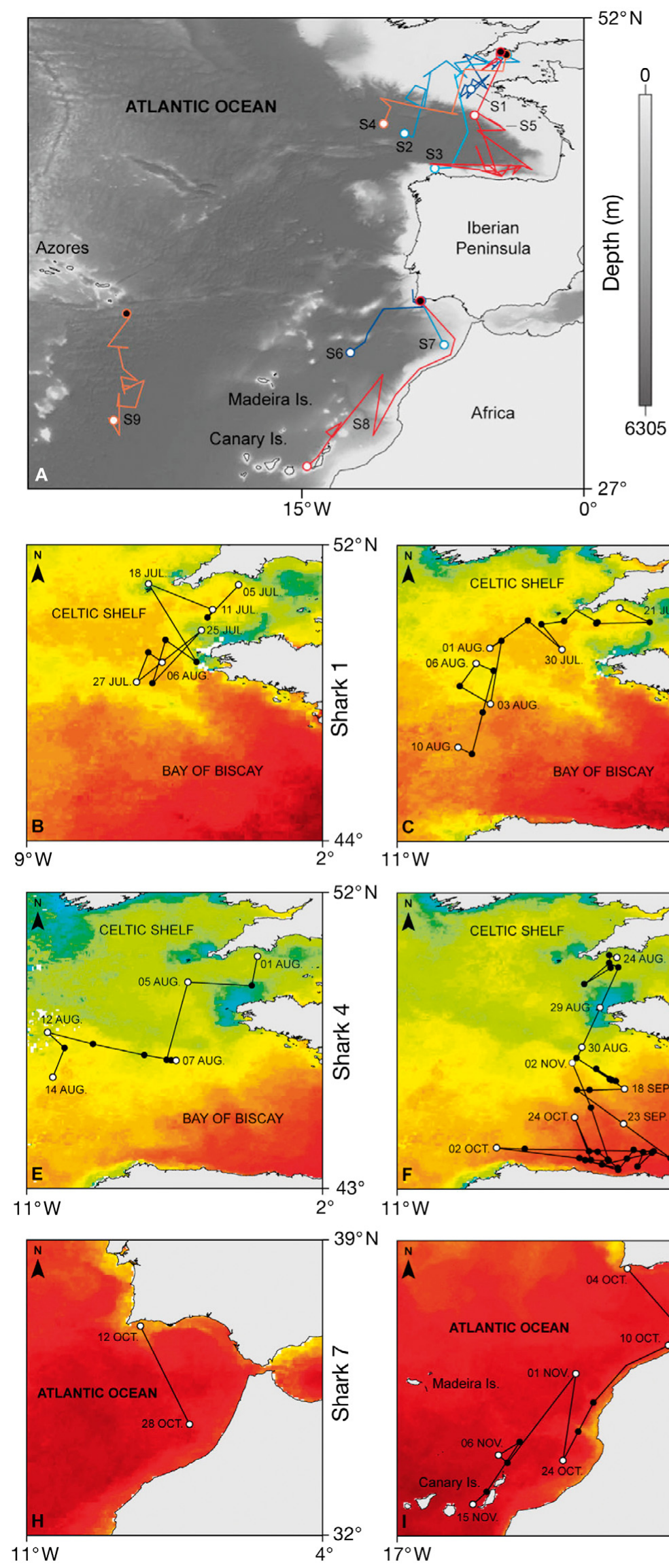
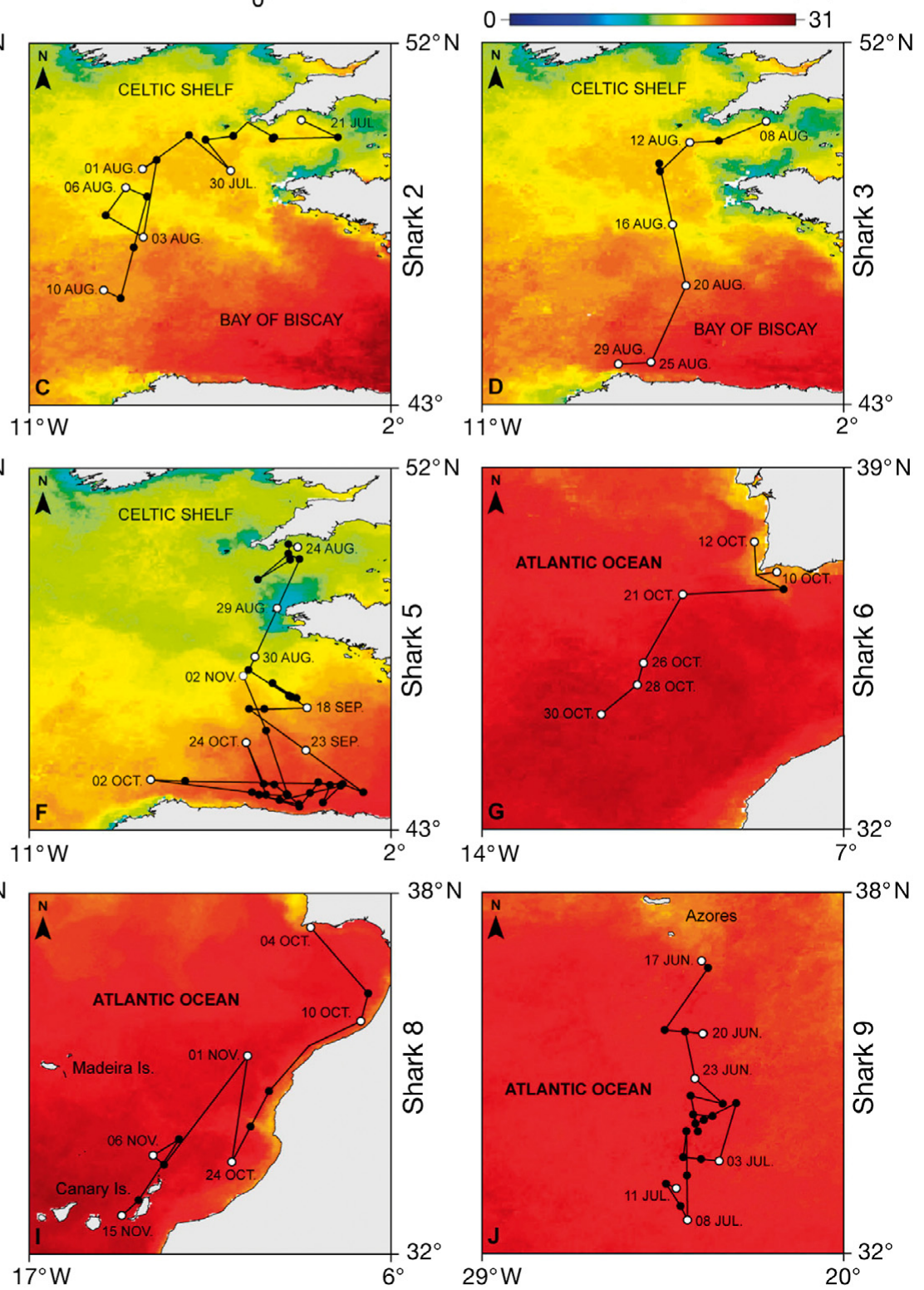

Fig. 1. Prionace glauca. Pop-off satellite-tagged blue shark movement patterns. (A) General movements overlaid on bathymetry; black circles denote tagging locations and white circles the pop-up/capture locations. (B to J) Individual tracks overlaid on sea surface temperature maps; white circles are geolocated positions with date

Sea surface temperature $\left({ }^{\circ} \mathrm{C}\right)$ $29^{\circ} \mathrm{W}$ 


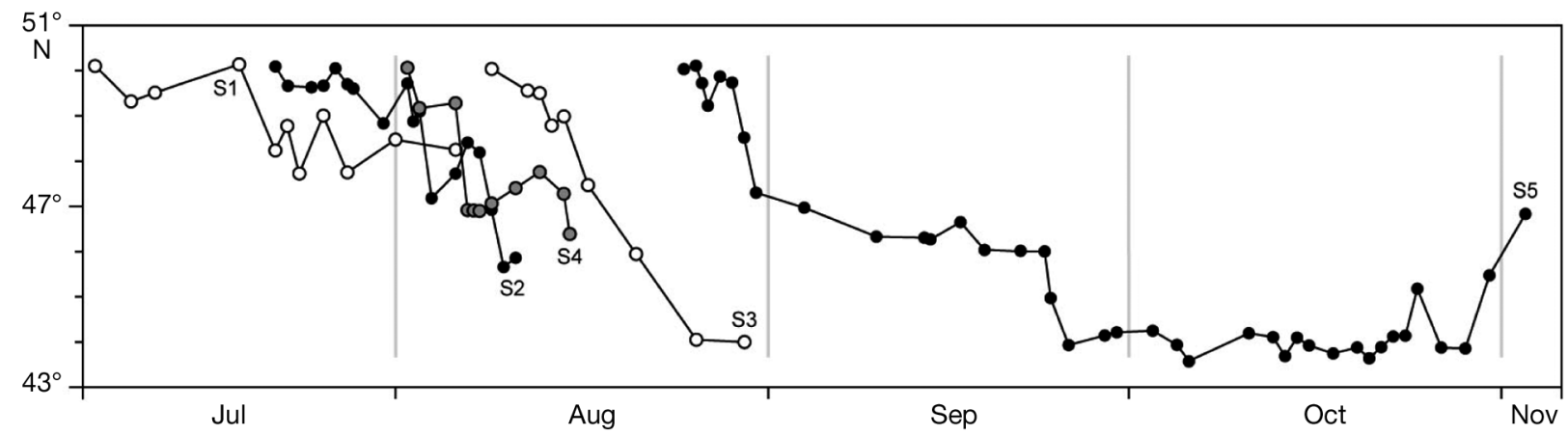

Fig. 2. Prionace glauca. Latitude estimates of the 5 blue sharks (S1 to S5) tagged in the English Channel in relation to time of year

The modified SMW statistical technique detected significant shifts in both depth use and water temperature during the horizontal trajectories of all sharks (Figs. 3 \& 4 - data not shown for S1). Shifts in TAD data were due to differences in depth use, whilst shifts in TAT were caused by either a change in depth or changes in vertical thermal structure, such as the presence of oceanic thermal fronts.

The depth-range use of all sharks tagged off southwest England that moved into deeper water (S2 to S5) shifted near the shelf edge. This change was linked to deeper diving $(>200 \mathrm{~m}$ ) in offshore waters (Fig. 3). A significant shift was also detected in the diving behaviour of Sharks 7 and 8 (tagged off Portugal) between the shelf and offshore waters (Fig. 4B,C). Likewise, a clear change in depth range use was also identified for S9, moving between near-island and oceanic waters off the Azores (Fig. 4D). The detection of behavioural shifts from coastal to offshore locations in sharks tagged in different geographical regions enabled coastal behaviour to be distinguished from offshore behaviour.

Coastal behaviour of the sharks tagged in the English Channel in 2006 (S1 to S3) varied from those tagged in the same area in 2007 (S4 to S5). When in shelf waters, sharks tagged in 2006 appeared to utilise much of the available water column but occupied surface layers more often, spending at least $50 \%$ of their time between the surface and a depth of $20 \mathrm{~m}$ (e.g. S2 Phase $a / b$, S3 Phase $a$; Fig. 3A,B). S2 switched to a bimodal phase, showing surface-oriented behaviour together with a second depth range between 50 and $100 \mathrm{~m}$ where it spent $\sim 50 \%$ of its time. Depth-temperature profiles of the water column indicated sharks were diving through stratified water, with a thermocline at approximately 25 to $30 \mathrm{~m}$ (Fig. 5A,C). During Phase a, diving behaviour was frequently restricted to the mixed surface layer with periodic dives below the thermocline (Fig. 5B,D). In contrast to sharks tagged in 2006, vertical behaviour in sharks tagged in 2007 was highly irregular and surface layers were not occupied for as long (S4/S5 Phase a; Fig. 3C,D). Furthermore, profiles of water TAD indicated the water column was relatively isothermal and well mixed (Fig. 5E,G). Shelf surface waters in 2007 were also cooler than the year before (Fig. 1B-F). Moreover, the diving activity of Sharks 4 and 5 extended from the surface to the sea bottom in the shelf habitats occupied (Fig. 5F,H). Thermal habitats occupied by all English Channel tracked sharks in the coastal phase were similar, with water temperatures ranging between approximately 10 to $20^{\circ} \mathrm{C}$ (Fig. 3). Shark 1 experienced a significant shift in water temperature during Phase b, when it occupied waters off the southwest coast of England, an area with seasonally persistent, tidally induced thermal fronts (Fig. S3A in the supplement; www.int-res. com/articles/suppl/m406p265_app.pdf; see also Sims et al. 2003b).

Inshore/near-island vertical behaviour in Portugaltagged blue sharks was irregular and not surface oriented (Fig. 4). A similar pattern was displayed by sharks in the Celtic Sea shelf area in 2007. Depth-temperature profiles were also similar between regions, representing weakly stratified waters (Fig. 5I,K,M).

Near the shelf-edge and over deep water, blue sharks adopted either a surface-oriented or a depthoriented diving pattern, often switching between both. In the surface-oriented period, sharks usually spent high percentages (75 to $100 \%$ ) of their time at or near the surface, making frequent deep dives below $300 \mathrm{~m}$ (e.g. S2 Phase c, S5 Phase e, S8 Phase b; Figs. 3A,D \& $4 C)$. This behaviour was often associated with thermally stratified waters (e.g. Fig. 6A,C,E). Furthermore, maximum dive depth was regularly restricted to the surface mixed layer above the thermocline (e.g. Fig. 6B,D,F). The occupied thermal habitat was relatively constant during this surface-oriented phase, with blue sharks spending $>75 \%$ of the time in water temperatures ranging from 18 to $20^{\circ} \mathrm{C}$. Sharks $2,3,5$ and 8 experienced significant shifts in temperature in relation to fronts in the oceanic environment. From 
A SHARK 2

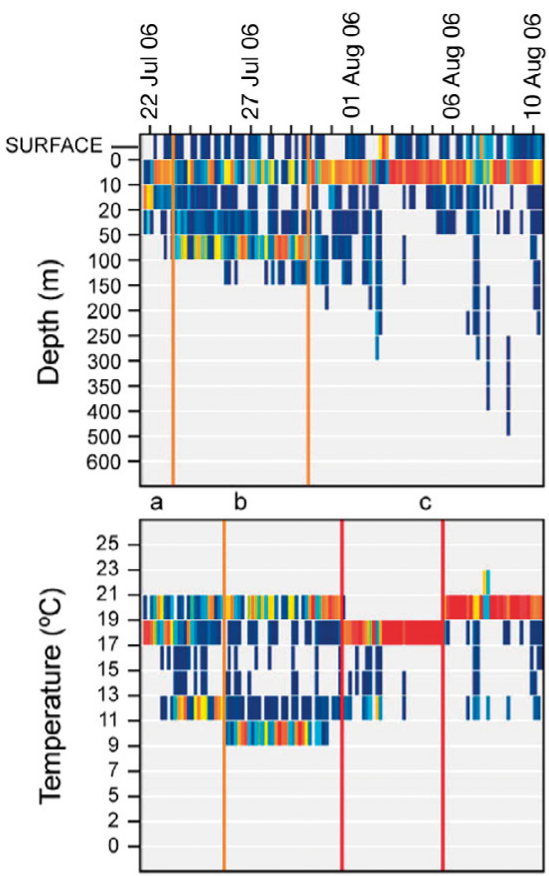

B SHARK 3

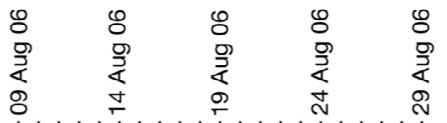
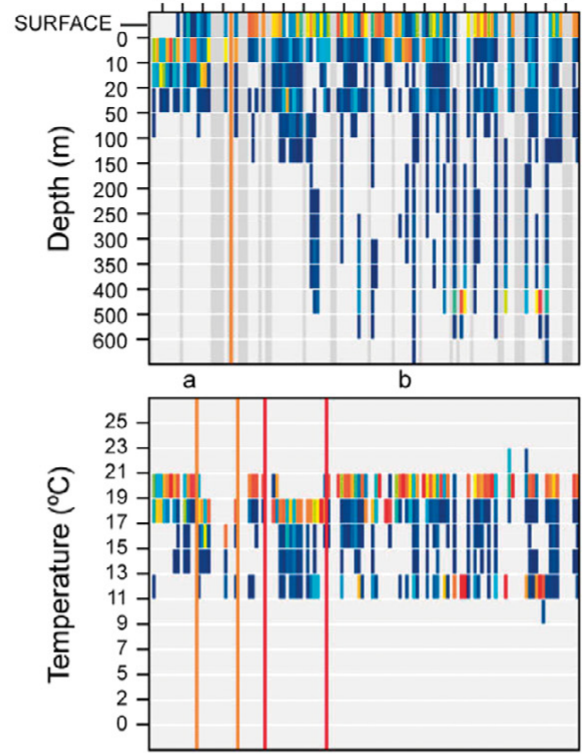

C SHARK 4
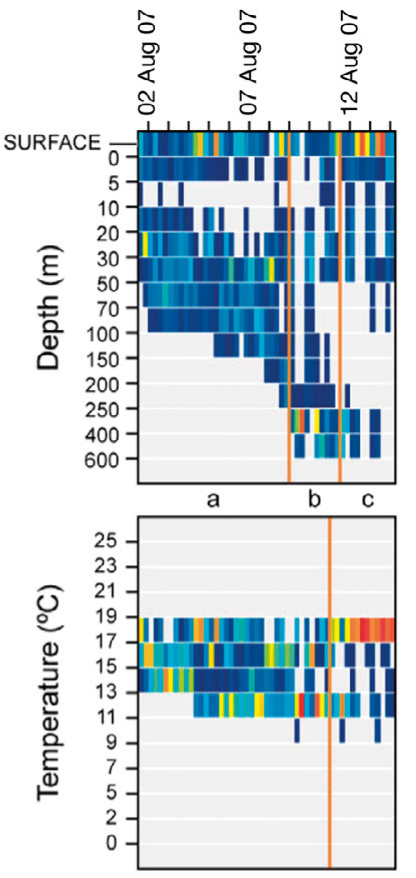

D SHARK 5

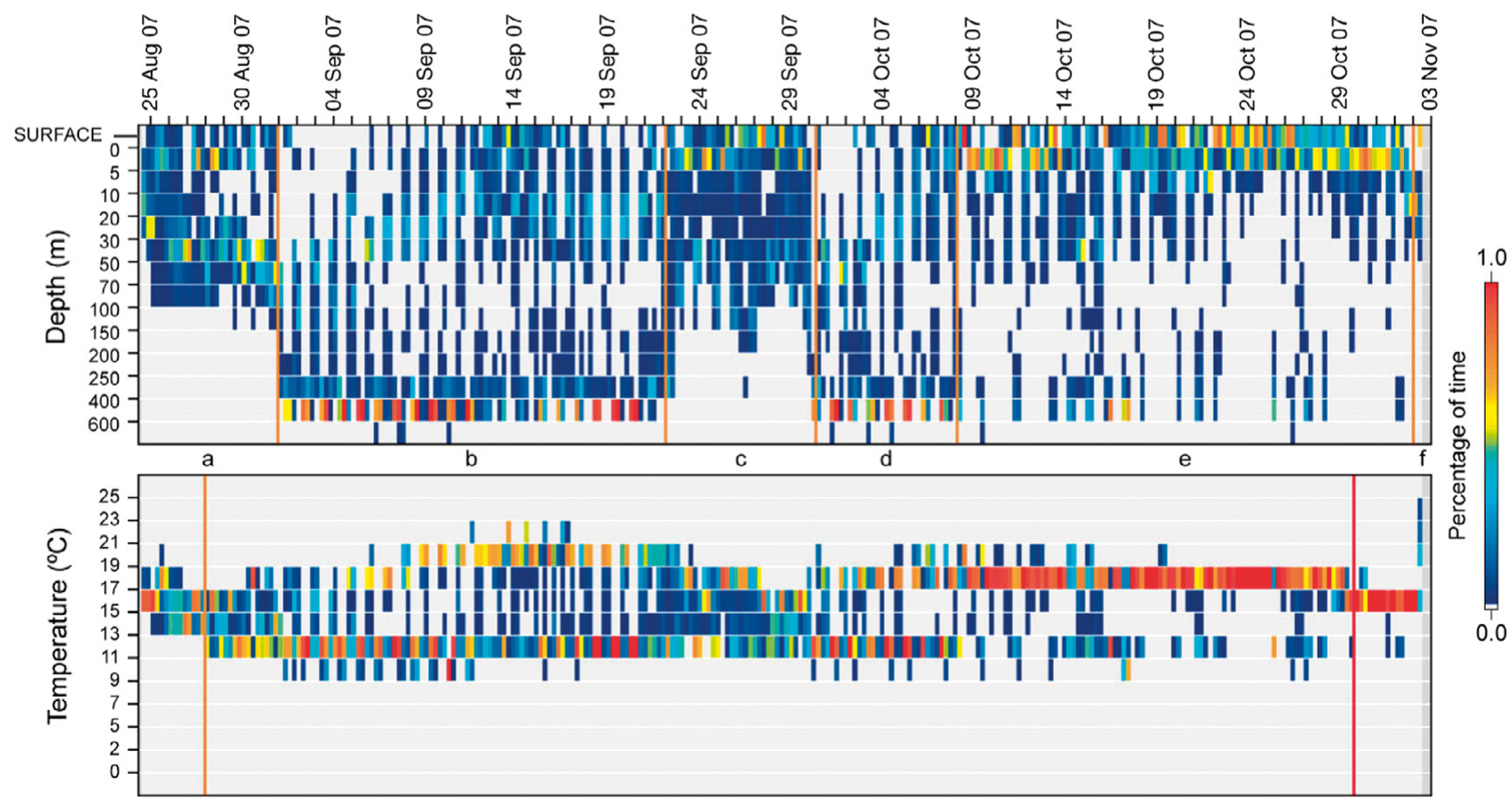

Fig. 3. Prionace glauca. Surface plots of time-at-depth and time-at-temperature (TAT) data for blue sharks tagged off England. (A to D) Shark 2 to Shark 5; vertical orange line shows significant shifts in data detected with the split-moving window procedure; vertical red lines are significant shifts in TAT data that are likely associated with a frontal area. Lowercase letters (a to f) correspond to split-moving behavioural phases

available SST remote sensing images, these shifts were either associated with shelf-edge or upwelling fronts (Fig. 1C,D,F,I).
Contrasting with the surface-oriented pattern, Sharks 3 to 5 switched to a depth-oriented behaviour, spent little or no time at the surface and made long 
A SHARK 6
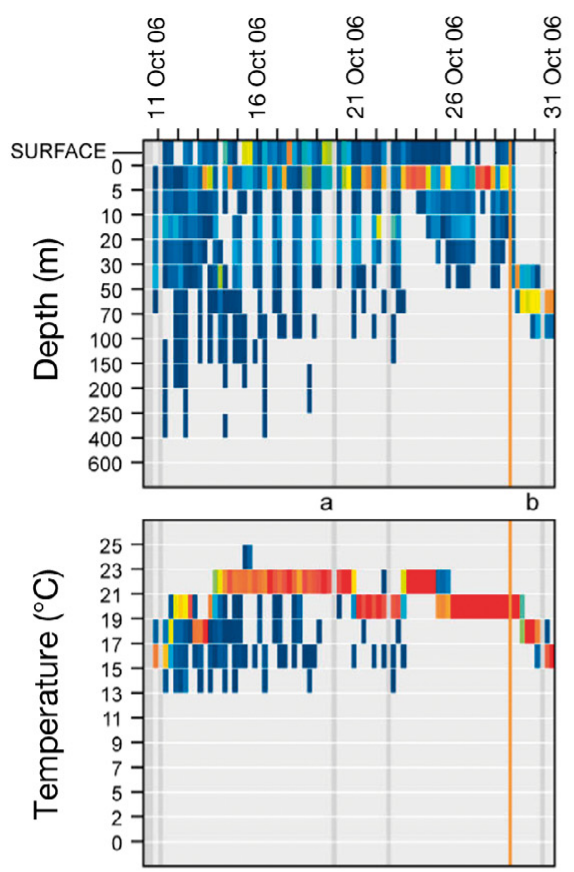

B SHARK 7
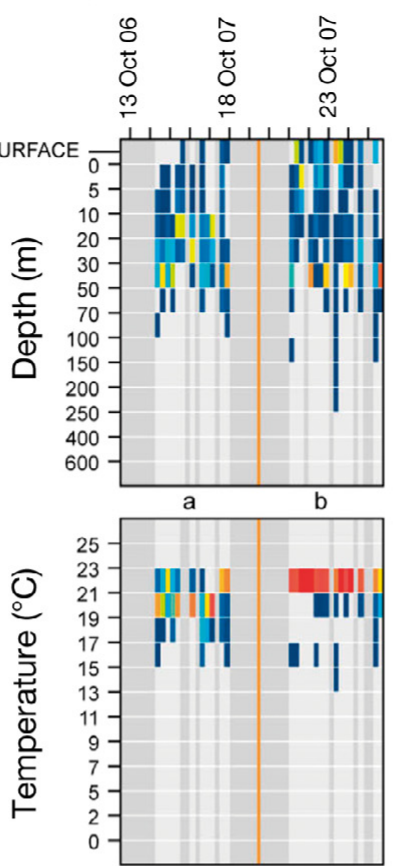

Fig. 4. Prionace glauca. Surface plots of timeat-depth and time-at-temperature (TAT) data for blue sharks tagged off Portugal. (A to D) Shark 6 to Shark 9; vertical orange line shows significant shifts in data detected with splitmoving window procedure; vertical red lines are significant shifts in TAT data that are likely associated with a frontal area. Lowercase letters $(\mathrm{a}, \mathrm{b})$ correspond to split-moving window behavioural phases

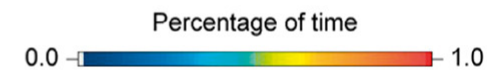

C SHARK 8

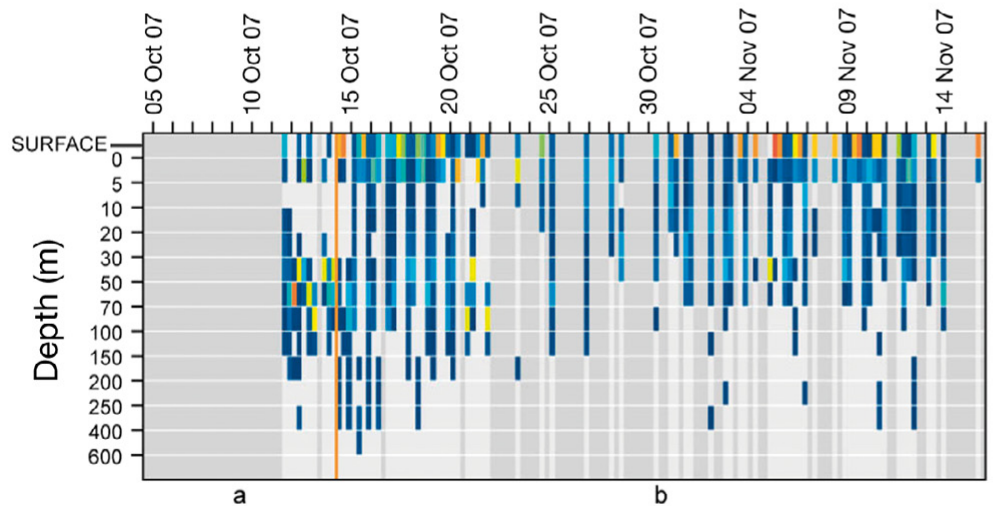

D SHARK 9

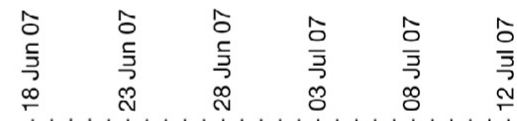
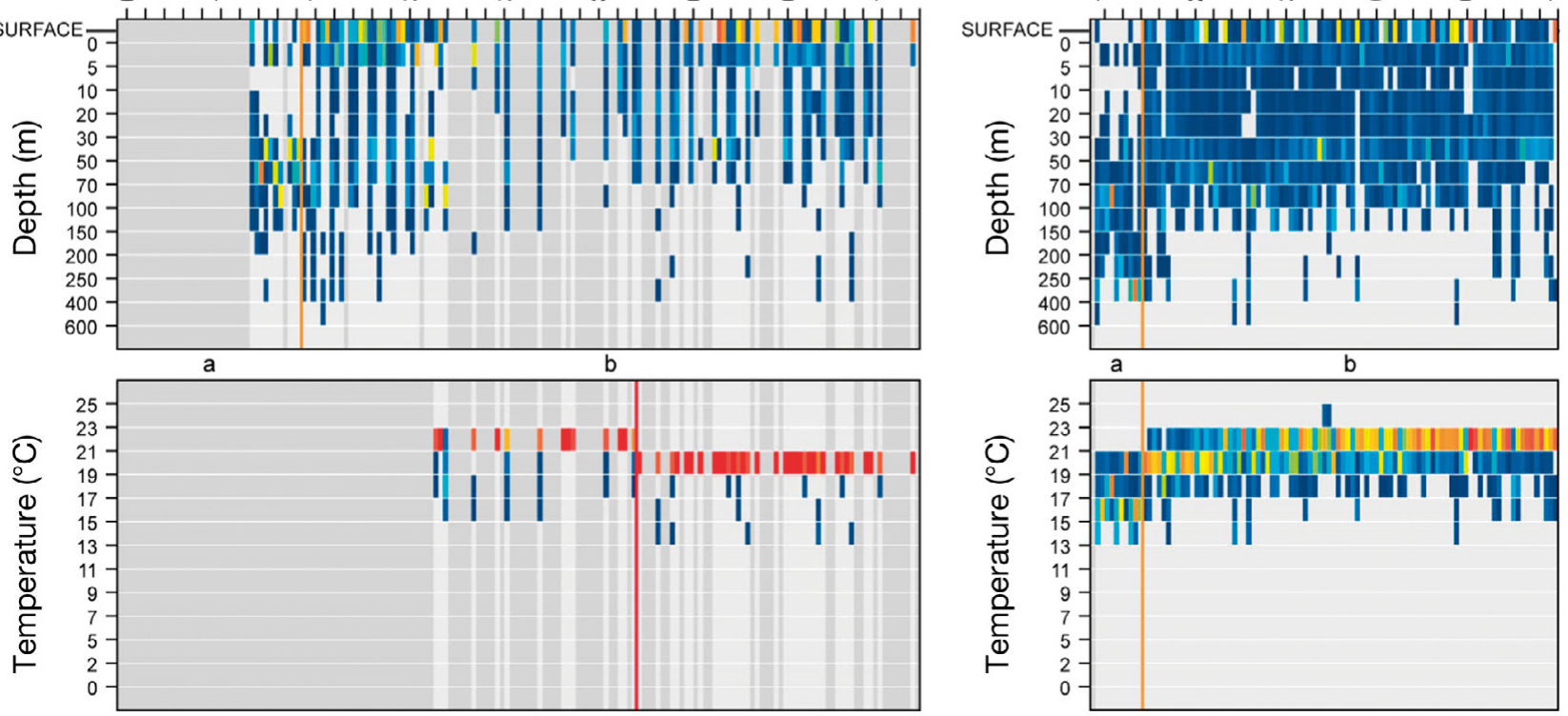

deep dives, exhibiting oscillatory swimming behaviour at depths between 300 and $700 \mathrm{~m}$ below the thermocline (e.g. S3 Phase b, S5 Phase b/d: Fig. 3B,D; see also Fig. $6 \mathrm{H}, \mathrm{J})$. These deep dives were usually performed in frontal or stratified water in the Bay of Biscay shelf break area (Fig. 6G,I). Due to the extended time spent in cold deep waters, the thermal habitat was irregular, with temperatures ranging from $\sim 10$ to $21^{\circ} \mathrm{C}$.

The diving pattern of Shark 9 also changed to a surface-oriented behaviour when in oceanic waters south of the Azores (Fig. 4D). However, this pattern was irregular, with the shark utilising the whole epipelagic layer from the surface down to $200 \mathrm{~m}$, with relatively 

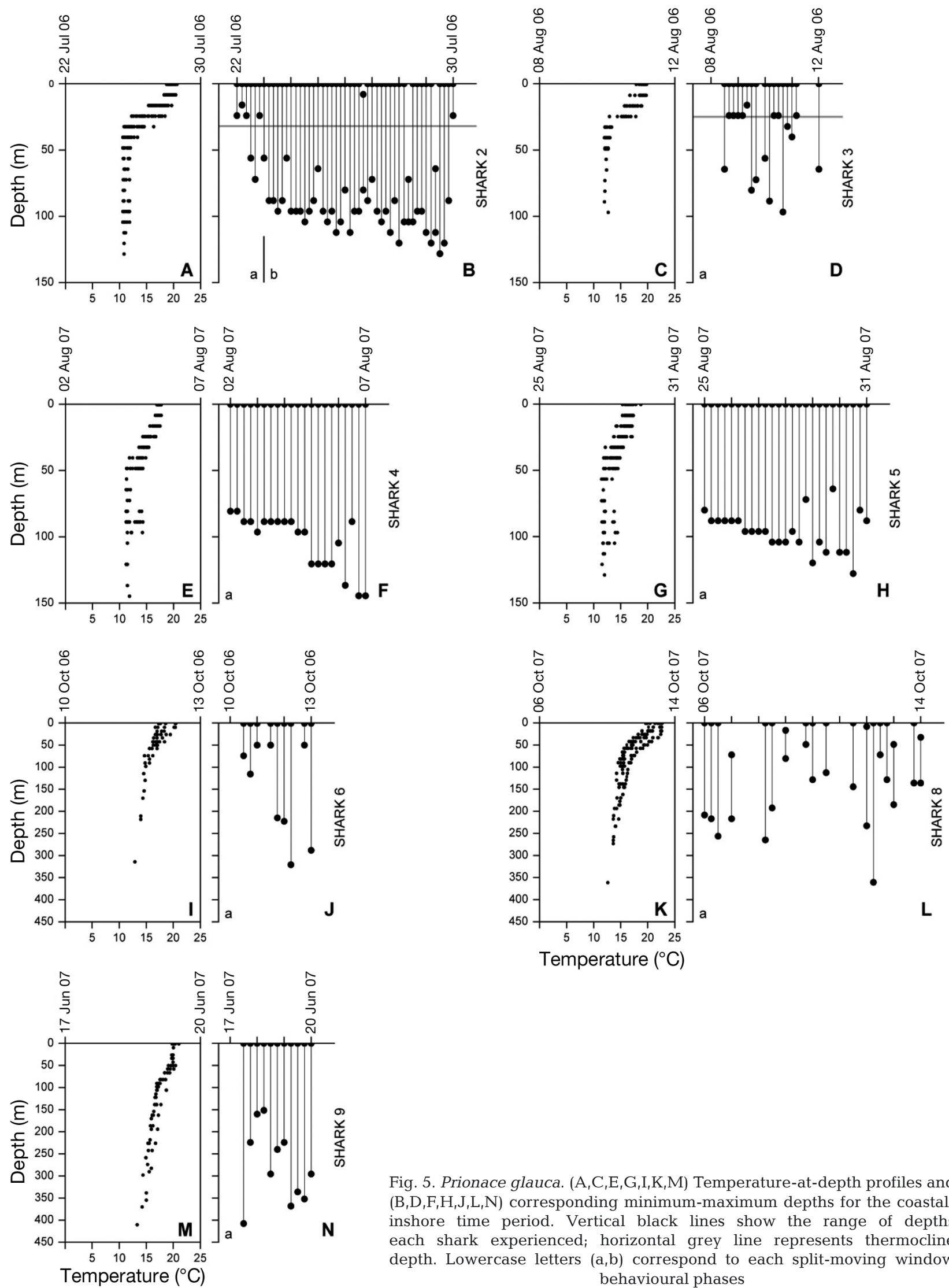

Fig. 5. Prionace glauca. $(\mathrm{A}, \mathrm{C}, \mathrm{E}, \mathrm{G}, \mathrm{I}, \mathrm{K}, \mathrm{M})$ Temperature-at-depth profiles and $(\mathrm{B}, \mathrm{D}, \mathrm{F}, \mathrm{H}, \mathrm{J}, \mathrm{L}, \mathrm{N})$ corresponding minimum-maximum depths for the coastal/ inshore time period. Vertical black lines show the range of depths each shark experienced; horizontal grey line represents thermocline depth. Lowercase letters $(a, b)$ correspond to each split-moving window behavioural phases 

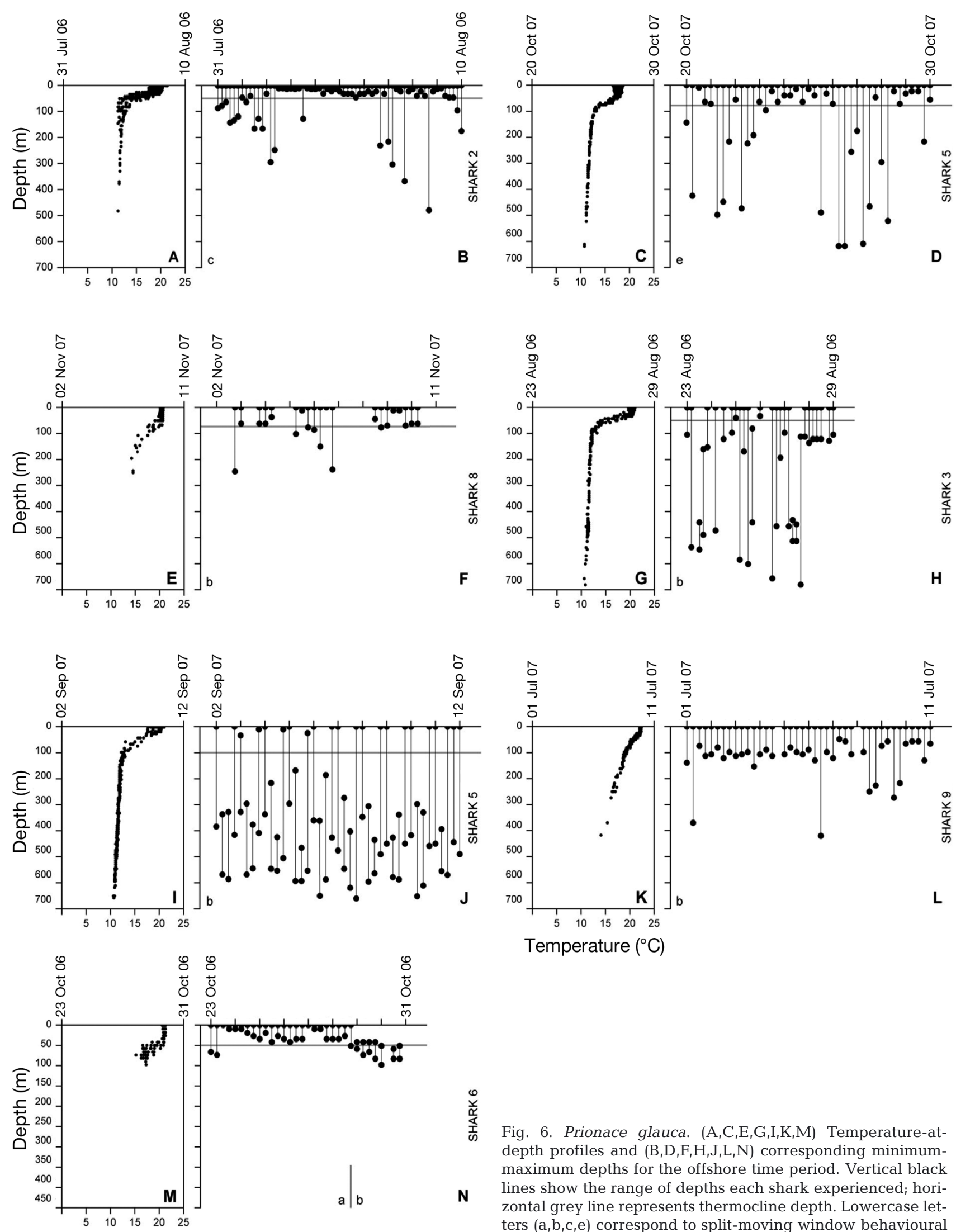

Temperature $\left({ }^{\circ} \mathrm{C}\right)$

0
$\frac{1}{\alpha}$
$\frac{1}{4}$
$\frac{1}{\omega}$

Fig. 6. Prionace glauca. (A, $, \mathrm{E}, \mathrm{G}, \mathrm{I}, \mathrm{K}, \mathrm{M})$ Temperature-atdepth profiles and $(\mathrm{B}, \mathrm{D}, \mathrm{F}, \mathrm{H}, \mathrm{J}, \mathrm{L}, \mathrm{N})$ corresponding minimummaximum depths for the offshore time period. Vertical black lines show the range of depths each shark experienced; horizontal grey line represents thermocline depth. Lowercase letters $(\mathrm{a}, \mathrm{b}, \mathrm{c}, \mathrm{e})$ correspond to split-moving window behavioural phases 
rapid sporadic dives to $\sim 400 \mathrm{~m}$ (Fig. 6L). Depthtemperature profiles indicated Shark 9 was diving across poorly stratified oceanic waters (Fig. 6K). Shark 6 also displayed a different behaviour from the surfaceoriented or depth-oriented pattern at the end of October, rapidly shifting to movements that were limited to waters below the thermocline at depths between 40 and $96 \mathrm{~m}$ (Figs. $4 \mathrm{~A} \& 6 \mathrm{M}, \mathrm{N}$ ).

\section{DISCUSSION}

This study provides new information on short to medium-term horizontal and vertical movements of juvenile and sub-adult blue sharks in the northeast Atlantic. Results show that female blue sharks tagged in the western English Channel in July and August remain associated with the shelf edge in that region and in the Bay of Biscay for periods up to $70 \mathrm{~d}$, indicating that proposed return migrations to warmer waters may be less rapid than supposed. In addition, juvenile blue shark movements are more extensive than previously realised, with individuals moving away from putative nursery areas off Portugal to the Canary Islands and areas with oceanic seamounts. Blue shark diving behaviour showed considerable variability (perhaps even behavioural plasticity) within and between individuals, whereby behavioural phases were generally linked to vertical thermal habitat in inshore areas and to possible changes in prey distribution or prey type in deeper water.

\section{Horizontal movements}

Movement of tracked blue sharks into the Bay of Biscay from tagging sites off southwest England generally agrees with earlier results from mark-recapture studies, where a number of sharks tagged in the English Channel were recaptured in the Bay of Biscay from July to November (Stevens 1976, 1990). In addition, tracking of blue sharks away from the shelf in summer months is indicative of a potential southerly migration in response to seasonal cooling of surface waters at higher latitudes (Fig. 2), since tag returns from south of $40^{\circ} \mathrm{N}$ have been described previously (Stevens 1976, 1990). Track reconstructions using the light level/SST geolocation technique represent only approximate movement paths (Nielsen et al. 2006, Sims et al. 2006b). Hence, estimates of the distances moved will be impacted by the inaccuracy of light-based geolocation (Bradshaw et al. 2007), which emphasises the need for the development of improved techniques for tracking fish with greater spatial accuracy (e.g. GPS: see Sims et al. 2009). Nonetheless, juvenile/sub-adult blue sharks tagged by us exhibited broad-scale summer/autumn horizontal movements, with high-space use of different oceanographic regions, including shelf, slope and oceanic water. Movement patterns of tagged blue sharks off the south coast of Portugal were also wide-ranging, with juvenile sharks $(<145 \mathrm{~cm}$ FL) displaying less site fidelity than indicated by previous mark-recapture studies (Stevens 1976, 1990, Queiroz et al. 2005). These juveniles showed some preference for shallower waters on the continental shelf. Shelf and shelf-edge areas in temperate regions of the north Atlantic are usually characterised by the presence of tidal thermal fronts, upwelling zones or shelf-edge fronts, particularly in warmer months (Sims et al. 2000, Sims et al. 2003b, McGregor et al. 2007). These are usually regions of higher primary production which support high plankton biomass (e.g. Stoecker et al. 1989) and which also attract large aggregations of schooling fish and pelagic predators (e.g. Sims \& Quayle 1998, Sedberry \& Loefer 2001, Zainuddin et al. 2006). Since these regions may present habitats with a higher probability of prey encounter, the movements of tracked blue sharks may be the result of searching behaviours linked to the targeting of shelf and slope areas (Sims \& Quayle 1998, Sims et al. 2008). Blue sharks are known to prey on pelagic fish such as clupeids and mackerel in the English Channel (Stevens 1973), where large schools are seasonally available in summer months (Southward et al. 2004). Likewise, blue sharks have been shown to aggregate in the California Current upwelling system in the northeastern Pacific (Weng et al. 2005).

Movements of blue sharks into deep (>2000 m) offshore waters south of the Azores and in the Bay of Biscay were also observed in this study. Similar movements have been described for other large marine vertebrates such as leatherback turtles (Hays et al. 2004), sharks (Weng et al. 2007), tuna and billfish (Stokesbury et al. 2007, Goodyear et al. 2008). Although reasons for these migrations are largely unknown, they might be related to larger-scale movements linked to new foraging opportunities, namely with the availability of particular prey species at greater depths (Clarke \& Stevens 1974) or in response to local oceanographic conditions (e.g. decreasing surface water temperatures). However, parturition and mating activities of sharks have also been related to such movements (Weng et al. 2005, 2007). Recently, catch records from longline fisheries revealed the existence of dense, adult male blue shark aggregations in offshore waters and submarine seamounts south of the Azores, which most likely serve as mating areas (Litvinov 2006). Moreover, a late spring/early summer breeding season has been proposed for blue sharks in the north Atlantic (Pratt 
1979). Consequently, mating activities cannot be discounted as a possible explanation for the southerly movement of Shark 9 (a mature male) into oceanic waters.

\section{Vertical movements and behaviour}

Tracked blue sharks showed considerable variation in vertical habitat use in coastal areas, apparently modifying their behaviour in response to contrasting characteristics in the thermal structure of the water column (but which could be a proxy for other changes they responded to, e.g. prey distribution, density or type). Profiles of water temperature at depth varied from stratified waters, where sharks showed some preference for surface layers, to well-mixed or weakly stratified waters, where behaviour was irregular with no discernible pattern. Likewise, changes in behaviour in the transition between coastal and off-shelf areas of southern Portugal were coincident with increased stratification of the water column. Shifts in diving patterns from mixed to well-stratified waters have been described for the plankton-feeding basking shark and the predatory porbeagle shark Lamna nasus in shelf and shelf-edge regions (Sims et al. 2005, Pade et al. 2009). This suggests blue shark diving behaviour may be related to physical characteristics of the water column, which can directly or indirectly influence the depth and spatial distribution of prey resources (Sims et al. 2005).

Over deep water, blue sharks tracked in the present study often spent large proportions of time in the warm surface layer above the thermocline. A similar behaviour was described for blue sharks in the Pacific Ocean, where tagged individuals spent $\sim 65 \%$ of their time above $50 \mathrm{~m}$ (Weng et al. 2005), whilst blue sharks off Hawaii often moved within the upper $220 \mathrm{~m}$, with occasional dives down to depths of 500 to $600 \mathrm{~m}$ (Moyes et al. 2006). Furthermore, surface-oriented behaviour has been observed in other sharks (Sepulveda et al. 2004), tuna (Marcinek et al. 2001) and billfish (Goodyear et al. 2008). Assuming that time spent at the surface may be a function of prey abundance or the higher probability of prey capture there (Sims et al. 2003a), these observations could indicate that the epipelagic zone is an important foraging habitat for most oceanic predators. As thermal habitat during this surface phase was, in general, consistent vertically for the blue sharks we tracked, it is also possible that high percentages of time at the surface could be related to behavioural thermo-regulation (Carey \& Scharold 1990, Cartamil \& Lowe 2004). In the present study, sharks often performed deep, fast dives below $300 \mathrm{~m}$ in offshore locations. Graham et al. (2006) found that deep diving in whale sharks was non-randomly distributed, being more regular when a predictable food source was apparently no longer available. A similar pattern has been observed in a leatherback turtle, with more deep dives being performed after the turtle left a suitable prey field (Doyle et al. 2008). Hence, regular vertical movements may represent prey-searching behaviour, especially when prey densities at the surface are sparse, and might provide optimal foraging of the water column, as crossing multiple water layers would increase the probability of detecting prey olfactory trails which are moving horizontally in water layers of different physical properties (Carey \& Scharold 1990, Sims et al. 2003b).

At the shelf-edge, abrupt transitions between surfaceoriented and depth-oriented behaviour of tracked blue sharks were possibly linked to changes in prey distribution. In terms of optimal foraging theory, predators should maximise time spent in a prey patch. Hence, the fact that tracked blue sharks stayed at depth, usually between 300 and $700 \mathrm{~m}$, could indicate successful foraging at those depths. Nonetheless, this vertical shift in depths occupied could also be associated with a change in prey type as the sharks moved from coastal to off-shelf habitats. Previous studies show that the stomach contents of blue sharks caught in the English Channel were mainly composed of epipelagic schooling fish (Stevens 1973), whereas blue sharks in the Bay of Biscay fed mostly on squid species that most likely occurred in deep water (Clarke \& Stevens 1974). Since oscillatory swimming was observed during the deeper diving period in our study, this suggests the possibility that prey-specific search strategies may also be involved in the behavioural transition to a deeper, depth-directed pattern. Similar patterns of behaviour to this have been observed in other marine predators. For example, deep diving in school sharks Galeorhinus galeus was also linked to foraging, with sharks following vertically migrating prey such as squid (West \& Stevens 2001). Moreover, many penguin species also shift their behaviour in relation to changes in prey location or type (see Green et al. 2005). In particular, king penguins Aptenodytes patagonicus dived deeper and longer as they switched diet from fish to squid (Moore et al. 1999). The bimodal behaviour displayed by Shark 2 in shallow water could represent foraging, implying the shark was searching for both pelagic species above the thermocline and benthic prey near or at the bottom, where blue sharks are known to feed (Stevens 1973).

Two blue sharks exhibited diving patterns in oceanic waters that differed from the surface-oriented or depth-oriented behaviours. The irregular swimming of Shark 9 south of the Azores might have been linked to the water column thermal profile (discussed above). 
However, the rapid oscillatory behaviour observed from the surface to $200 \mathrm{~m}$ could also have been related to mating. A comparable behaviour was described for a white shark in an offshore focal area in the eastern Pacific Ocean; Weng et al. (2007) proposed that this oscillatory behavour was possibly related to courtship activities. Equally, the surface avoidance behaviour displayed by a juvenile blue shark (S6) in our study, which restricted dives to depths below the thermocline, may represent a strategy to avoid surface-layer dwelling predators. Satellite tracked opah Lampris guttatus were found to limit night dives to depths below $50 \mathrm{~m}$, perhaps to avoid predation by sharks (Polovina et al. 2007).

\section{Fisheries and conservation}

The global status of blue shark populations was recently evaluated as near threatened, with an estimated 10.7 million blue sharks being killed each year (Clarke et al. 2006a,b, Dulvy et al. 2008). In the western North Atlantic alone, it is estimated that blue sharks declined by $60 \%$ between 1986 and 2000 due to high fishing pressure (Baum et al. 2003). The largescale movements and high-space use displayed by blue sharks in the present study, using both coastal and deep-water fishing areas, could play a role in exacerbating such declines. Of particular concern are the observed wide-ranging movements of juvenile blue sharks, crossing national political-economic boundaries. Hence, the large-scale, trans-national area occupied by juvenile blue sharks within this 'nursery' further complicates any future management or conservation initiatives (Baum et al. 2003), which would require internationally coordinated action. Moreover, while the pattern appears complex, there is evidence that blue sharks exhibit age and sexual segregation in different regions of the North Atlantic, indicating different components of the population may face differential risk from fisheries depending on which geographical regions they occupy at specific times (Mucientes et al. 2009). This may act to accelerate declines further.

Satellite-linked tags have been used recently to estimate fishing mortality rates for turtles (Hays et al. 2003) and billfish (Graves \& Horodysky 2008). In our study, longliner capture rates of tagged blue sharks seem reasonably high over the relatively short tracking periods (13 to $70 \mathrm{~d}$ ), with 1 blue shark (S5) out of 11 tagged individuals being captured by longline and the tag returned (see Fig. S3B for capture signal in tag data). In a parallel study in the same general area, out of 6 juvenile blue sharks fitted with finmounted Argos transmitters, 2 were captured just 4 mo after tagging (N. Queiroz \& D. W. Sims unpubl. data). Therefore, from these preliminary estimates, fishing mortality for blue shark ranges from 9 to as high as $33 \%$.

Acknowledgements. We gratefully acknowledge funding from the Save Our Seas Foundation and the UK Natural Environment Research Council (NERC) Oceans 2025 Strategic Research Programme (Theme 6, Science for Sustainable Marine Resources) through grant awards to D.W.S. N.Q. was funded by a Fundação para a Ciência e a Tecnologia (FCT) PhD grant SFRH/BD/21354/2005. D.W.S. was supported by a Marine Biological Association Senior Research Fellowship. This research was facilitated through the European Tracking of Predators in the Atlantic (EUTOPIA) programme in the European Census of Marine Life.

\section{LITERATURE CITED}

Baum JK, Myers RA, Kehler DG, Worm B, Harley SJ, Doherty PA (2003) Collapse and conservation of shark populations in the northwest Atlantic. Science 299:389-392

Bradshaw CJA, Sims DW, Hays GC (2007) Measurement error causes scale-dependent threshold erosion of biological signals in animal movement data. Ecol Appl 17: 628-638

Bruce BD, Stevens JD, Malcolm H (2006) Movements and swimming behaviour of white sharks (Carcharodon carcharias) in Australian waters. Mar Biol 150:161-172

Carey FG, Scharold JV (1990) Movements of blue sharks (Prionace glauca) in depth and course. Mar Biol 106:329-342

Cartamil DP, Lowe CG (2004) Diel movement patterns of ocean sunfish Mola mola off southern California. Mar Ecol Prog Ser 266:245-253

Casey JG (1985) Transatlantic migrations of the blue shark; a case history of cooperative shark tagging. In: Stroud RH (ed) World angling resources and challenges. Proceedings of the First World Angling Conference, Cap d'Agde, France. International Game Fish Association, Fort Lauderdale, FL, p 253-268

Charrassin JB, Bost CA (2001) Utilisation of the oceanic habitat by king penguins over the annual cycle. Mar Ecol Prog Ser 221:285-297

Clarke MR, Stevens JD (1974) Cephalopods, blue sharks and migration. J Mar Biol Assoc UK 54:949-957

Clarke SC, Magnussen JE, Abercrombie DL, McAllister MK, Shivji MS (2006a) Identification of shark species composition and proportion in the Hong Kong shark fin market based on molecular genetics and trade records. Conserv Biol 20:201-211

> Clarke SC, McAllister MK, Milner-Gulland EJ, Kirkwood GP and others (2006b) Global estimates of shark catches using trade records from commercial markets. Ecol Lett 9:1115-1126

Cornelius JM, Reynolds JF (1991) On determining the statistical significance of discontinuities within ordered ecological data. Ecology 72:2057-2070

> Dagorn L, Bach P, Josse E (2000) Movement patterns of large bigeye tuna (Thunnus obesus) in the open ocean, determined using ultrasonic telemetry. Mar Biol 136:361-371

> Doyle TK, Houghton JDR, O'Súilleabháin PF, Hobson VJ, Marnell F, Davenport J, Hays GC (2008) Leatherback turtles satellite-tagged in European waters. Endang Species Res 4:23-31 
Dulvy NK, Baum JK, Clarke S, Compagno LJV and others (2008) You can swim but you can't hide: the global status and conservation of oceanic pelagic sharks and rays. Aquat Conserv: Mar Freshw Ecosyst 18:459-482

Folkow LP, Blix AS (1999) Diving behaviour of hooded seals (Cystophora cristata) in the Greenland and Norwegian Seas. Polar Biol 22:61-74

Folkow LP, Nordøy ES, Blix AS (2004) Distribution and diving behaviour of harp seals (Pagophilus groenlandicus) from the Greenland Sea stock. Polar Biol 27:281-298

Goodyear CP, Luo J, Prince ED, Hoolihan JP, Snodgrass D, Orbesen ES, Serafy JE (2008) Vertical habitat use of Atlantic blue marlin Makaira nigricans: interaction with pelagic longline gear. Mar Ecol Prog Ser 365:233-245

Graham RT, Roberts CM, Smart JCR (2006) Diving behaviour of whale sharks in relation to a predictable food pulse. J R Soc Interface 3:109-116

Graves JE, Horodysky AZ (2008) Does hook choice matter? Effects of three circle hooks models on post-release survival of white marlin. N Am J Fish Manag 28:471-480

Green JA, Boyd IL, Woakes AJ, Warren NL, Butler PJ (2005) Behavioural flexibility during year-round foraging in macaroni penguins. Mar Ecol Prog Ser 296:183-196

Gunn JS, Patterson TA, Pepperell JG (2003) Short-term movement and behaviour of black marlin Makaira indica in the Coral Sea as determined through a pop-up satellite archival tagging experiment. Mar Freshw Res 54:515-525

> Hays GC, Broderick AC, Godley BJ, Luschi P, Nichols WJ (2003) Satellite telemetry suggests high levels of fishing induced mortality for marine turtles. Mar Ecol Prog Ser 262:305-308

- Hays GC, Houghton JDR, Isaacs C, King RS, Lloyd C, Lovell P (2004) First records of oceanic dive profiles for leatherback turtles, Dermochelys coriacea, indicate behavioural plasticity associated with long-distance migration. Anim Behav 67:733-743

- Hays GC, Hobson VJ, Metcalfe JD, Righton D, Sims DW (2006) Flexible foraging movements of leatherback turtles across the North Atlantic Ocean. Ecology 87:2647-2656

Henderson AC, Flannery K, Dunne J (2001) Observations on the biology and ecology of the blue shark in the north-east Atlantic. J Fish Biol 58:1347-1358

Holts DB, Bedford DW (1993) Horizontal and vertical movements of the shortfin mako shark, Isurus oxyrinchus, in the southern California Bight. Aust J Mar Freshw Res 44: 901-909

Hulbert LB, Aires-da-Silva AM, Gallucci VF, Rice JS (2005) Seasonal foraging movements and migratory patterns of female Lamna ditropis tagged in Prince William Sound, Alaska. J Fish Biol 67:490-509

Kohler NE, Turner PA, Hoey JJ, Natanson LJ, Briggs R (2002) Tag and recapture data for three pelagic shark species: blue shark (Prionace glauca), shortfin mako (Isurus oxyrinchus), and porbeagle (Lamna nasus) in the North Atlantic Ocean. Col Vol Sci Pap ICCAT 54:1231-1260

Litvinov FF (2006) On the role of dense aggregations of males and juveniles in the functional structure of the range of the blue shark, Prionace glauca. J Ichthyol 46:613-624

Lutcavage ME, Brill RW, Skomal GB, Chase BC, Goldstein JL, Tutein J (2000) Tracking adult North Atlantic bluefin tuna (Thunnus thynnus) in the northwestern Atlantic using ultrasonic telemetry. Mar Biol 137:347-358

Marcinek DJ, Blackwell SB, Dewar H, Freund EV and others (2001) Depth and muscle temperature of Pacific bluefin tuna examined with acoustic and pop-up satellite archival tags. Mar Biol 138:869-885

McGregor HV, Dima M, Fischer HW, Mulitza S (2007) Rapid 20th-century increase in coastal upwelling off northwest Africa. Science 315:637-639

McMahon CR, Hays GC (2006) Thermal niche, large-scale movements and implications of climate change for a critically endangered marine vertebrate. Glob Change Biol 12:1330-1338

Mejuto J, García-Cortés B, de la Serna JM (2003) An overview of the activity of the Spanish surface longline fleet targeting swordfish (Xiphias gladius) during 2000, with special reference to the Atlantic Ocean. Col Vol Sci Pap ICCAT 55:1485-1494

Moore GJ, Wienecke BC, Robertson G (1999) Seasonal change in foraging areas and dive depths of breeding king penguins at Heard Island. Polar Biol 21:376-384

Moyes CD, Fragoso N, Musyl MK, Brill RW (2006) Predicting post-release survival in large pelagic fish. Trans Am Fish Soc 135:1389-1397

Mucientes GR, Queiroz N, Sousa LL, Tarroso P, Sims DW (2009) Sexual segregation of pelagic sharks and the potential threat from fisheries. Biol Lett 5:156-159

Nakano H, Matsunaga H, Okamoto H, Okazaki M (2003) Acoustic tracking of bigeye thresher shark Alopias superciliosus in the eastern Pacific Ocean. Mar Ecol Prog Ser 265:255-261

> Nielsen A, Bigelow KA, Musyl MK, Sibert JR (2006) Improving light-based geolocation by including sea surface temperature. Fish Oceanogr 15:314-325

Pade NG, Queiroz N, Humphries NE, Witt MJ, Jones CS, Noble LR, Sims DW (2009) First results from satellitelinked archival tagging of porbeagle shark, Lamna nasus: area fidelity, wider-scale movements and plasticity in diel depth changes. J Exp Mar Biol Ecol 370:64-74

Polovina JJ, Hawn D, Abecassis M (2007) Vertical movement and habitat of opah (Lampris guttatus) in the central North Pacific recorded with pop-up archival tags. Mar Biol 153: $257-267$

Pratt HL (1979) Reproduction in the blue shark, Prionace glauca. Fish Bull 77:445-470

Queiroz N, Lima FP, Maia A, Ribeiro PA, Correia JPS, Santos AM (2005) Movements of blue shark, Prionace glauca, in the north-east Atlantic based on mark-recapture data. J Mar Biol Assoc UK 85:1107-1112

Sedberry GR, Loefer JK (2001) Satellite telemetry tracking of swordfish, Xiphias gladius, off the eastern United States. Mar Biol 139:355-360

- Sepulveda CA, Kohin S, Chan C, Vetter R, Graham JB (2004) Movement patterns, depth preferences, and stomach temperature of free-swimming juvenile mako sharks, Isurus oxyrinchus, in the Southern California Bight. Mar Biol 145:191-199

Shepard ELC, Ahmed MZ, Southall EJ, Witt MJ, Metcalfe JD, Sims DW (2006) Diel and tidal rhythms in diving behaviour of pelagic sharks identified by signal processing of archival tagging data. Mar Ecol Prog Ser 328: 205-213

Sims DW, Quayle VA (1998) Selective foraging behaviour of basking sharks on zooplankton in a small-scale front. Nature 393:460-464

Sims DW, Southall EJ, Quayle VA, Fox AM (2000) Annual social behaviour of basking sharks associated with coastal front areas. Proc Biol Sci 267:1897-1904

> Sims DW, Southall EJ, Merret DA, Sanders J (2003a) Effects of zooplankton density and diel period on surface-swimming duration of basking sharks. J Mar Biol Assoc UK 83: 643-646

> Sims DW, Southall EJ, Richardson AJ, Reid PC, Metcalfe JD (2003b) Seasonal movements and behaviour of basking 
sharks from archival tagging: no evidence of winter hibernation. Mar Ecol Prog Ser 248:187-196

Sims DW, Southall EJ, Tarling GA, Metcalfe JD (2005) Habitatspecific normal and reverse diel vertical migration in the plankton-feeding basking shark. J Anim Ecol 74:755-761

Sims DW, Wearmouth VJ, Southall EJ, Hill JM and others (2006a) Hunt warm, rest cool: bioenergetic strategy underlying diel vertical migration of a benthic shark. J Anim Ecol 75:176-190

Sims DW, Witt MJ, Richardson AJ, Southall EJ, Metcalfe JD (2006b) Encounter success of free-ranging marine predator movements across a dynamic prey landscape. Proc Biol Sci 273:1195-1201

Sims DW, Southall EJ, Humphries NE, Hays GC and others (2008) Scaling laws of marine predator search behaviour. Nature 451:1098-1102

Sims DW, Queiroz N, Humphries NE, Lima FP, Hays GC (2009) Long-term GPS tracking of ocean sunfish Mola mola offers a new direction in fish monitoring. PLoS ONE 4:e7351, doi:10.1371/journal.pone.0007351

Southward AJ, Langmead O, Hardman-Mountford NJ, Aiken $\mathrm{J}$ and others (2004) Long-term oceanographic and ecological research in the western English Channel. Adv Mar Biol 47:1-105

Stevens JD (1973) Stomach contents of the blue shark (Prionace glauca L.) off south-west England. J Mar Biol Assoc UK 53:357-361

Stevens JD (1976) First results of shark tagging in the northeast Atlantic, 1972-1975. J Mar Biol Assoc UK 56:929-937

Stevens JD (1990) Further results from a tagging study of pelagic sharks in the north-east Atlantic. J Mar Biol Assoc UK 70:707-720

Stoecker DK, Taniguchi A, Michaels AE (1989) Abundance of

Editorial responsibility: Matthias Seaman,

Oldendorf/Luhe, Germany autotrophic, mixotrophic and heterotrophic planktonic ciliates in shelf and slope waters. Mar Ecol Prog Ser 50: 241-254

- Stokesbury MJW, Cosgrove R, Boustany A, Browne D, Teo SLH, O'Dor RK, Block BA (2007) Results of satellite tagging of Atlantic bluefin tuna, Thunnus thynnus, off the coast of Ireland. Hydrobiologia 582:91-97

Takahashi M, Okamura H, Yokawa K, Okazaki M (2003) Swimming behaviour and migration of a swordfish recorded by an archival tag. Mar Freshw Res 54:527-534

> Teo SLH, Boustany AM, Dewar H, Stokesbury MJW and others (2007) Annual migrations, diving behavior, and thermal biology of Atlantic bluefin tuna, Thunnus thynnus, on their Gulf of Mexico breeding grounds. Mar Biol 151:1-18

Wall SM, Bradshaw CJA, Southwell CJ, Gales NJ, Hindell MA (2007) Crabeater seal diving behaviour in eastern Antarctica. Mar Ecol Prog Ser 337:265-277

- Weng KC, Castilho PC, Morrissette JM, Landeira-Fernandez AM and others (2005) Satellite tagging and cardiac physiology reveal niche expansion in salmon sharks. Science 310:104-106

- Weng KC, Boustany AM, Pyle P, Anderson SD, Brown A, Block BA (2007) Migration and habitat of white sharks (Carcharodon carcharias) in the eastern Pacific Ocean. Mar Biol 152:877-894

West GJ, Stevens JD (2001) Archival tagging of school shark, Galeorhinus galeus, in Australia: initial results. Environ Biol Fishes 60:283-298

Zainuddin M, Kiyofuji H, Saitoh K, Saitoh SI (2006) Using multi-sensor satellite remote sensing and catch data to detect ocean hot spots for albacore (Thunnus alalunga) in the northwestern North Pacific. Deep-Sea Res II 53: $419-431$

Submitted: September 8, 2009; Accepted: January 18, 2010 Proofs received from author(s): April 29, 2010 